\title{
Influence of Cow Age on Grazing Distribution in a Mixed-Conifer Forest
}

\author{
Kenric J. Walburger, ${ }^{1}$ Micah Wells, ${ }^{2}$ Martin Vavra, ${ }^{3}$ Timothy DelCurto, ${ }^{4}$ \\ Bruce Johnson, ${ }^{5}$ and Pricilla $\mathrm{Coe}^{5}$
}

\begin{abstract}
Authors are ${ }^{1}$ Range Supervisor, British Columbia Ministry of Forests and Range, Rocky Mountain Forest District, Cranbrook, BC V1C 7G1, Canada;
${ }^{2}$ Nutritional Consultant, CHS Nutrition, Hermiston, OR 97838, USA; ${ }^{3}$ Supervisory Rangeland Scientist, Pacific Northwest Research Station, US

Department of Agriculture Forest Service, Forestry and Range Sciences Laboratory, La Grande, OR 97850, USA; ${ }^{4}$ Associate Professor, Department of Animal Sciences, Eastern Oregon Agricultural Research Center, Oregon State University, Union, OR 97883, USA; and ${ }^{5}$ Wildlife Biologists, Oregon

Department of Fish and Wildlife, La Grande, OR 97850, USA.
\end{abstract}

\begin{abstract}
Optimal distribution of cattle on forested rangelands has long been a subject of concern specifically related to uniform and sustainable use of forage resources. Our objective was to determine if cow age influenced distribution and resource use on forested rangelands. This study was conducted from 1991 to 2001 at the US Department of Agriculture Starkey Experimental Forest and Range, northeastern Oregon, a mixed-conifer forested rangeland. We used 43039 locations of cattle taken from $1 \mathrm{~h}$ prior to sunrise until $4 \mathrm{~h}$ after sunrise and $4 \mathrm{~h}$ prior to sundown until $1 \mathrm{~h}$ after sundown from 15 July to 30 August to evaluate cattle distribution patterns during peak foraging time. Cattle were grouped into four age classes: 2- and 3-yr-old cattle, 4- and 5-yr-old cattle, 6- and 7 yr-old cattle, and cattle $\geq 8$ yr old. All age classes preferred areas with gentler slopes $(P<0.05)$, westerly aspects $(P<0.05)$, farther from water $(P<0.05)$, and with greater forage production $(P<0.05)$ than pasture averages. Cattle older than $3 \mathrm{yr}$ of age selected areas with less canopy closure $(P<0.05)$ than the mean value for the pasture. Young cows $(<4$ yr old $)$ selected lower elevations and steeper slopes than the oldest cows $(P<0.05)$. In summary, cow age and correspondingly its experience directly influences distribution patterns and forage resource use of cattle at the Starkey Experimental Forest and Range.
\end{abstract}

\section{Resumen}

La óptima distribución del ganado en pastoreo en pastizales con bosques ha sido una área de interés por mucho tiempo especialmente con respecto a una uniformidad y sustentabilidad del recurso forrajero. Nuestro objetivo fue determinar si la edad de las vacas afecta la distribución y el uso de los recursos en una zona de bosque. Este estudio fue llevado a cabo de 1991-2001 en el Noreste de Oregón en el USDA Starkey Experimental Forest and Range, en un pastizal mixto con coníferas. Utilizamos 43039 sitios del ganado tomados 1 hora antes del amanecer hasta 4 horas después del amanecer y 4 horas antes de la puesta del sol hasta 1 hora después de la puesta del sol desde el 15 de Julio hasta Agosto 30 para evaluar los patrones de la distribución del pastoreo durante el tiempo máximo del pastoreo. El ganado se agrupó en 4 clases de edades: ganado de 2 y 3 años de edad, ganado de 4 y 5 años, ganado de 6 y 7 años y ganado de $\geq 8$ años de edad. Todas las clases de ganado prefirieron áreas con pequeños lomeríos $(P<0.05)$, con orientación del oeste $(P<0.05)$, lejos del agua $(P<0.05)$, y con una producción mayor $(P<0.05)$, de forraje que el promedio del potrero. Ganado con más de 3 años de edad seleccionó áreas con una cobertura menos cerrada $(P<0.05)$, que el promedio del potrero. Las vacas jóvenes $(<$ de 4 años de edad) seleccionaron áreas con elevaciones bajas y áreas con mayor pendientes que las vacas viejas $(P<0.05)$. En resumen la edad de las vacas y la experiencia afecta directamente los patrones de distribución y el uso del forraje en el Starkey Experimental Forest and Range.

Key Words: beef cattle, distribution patterns, resource selection

\section{INTRODUCTION}

Management of cattle distribution patterns is the basis for many current federal land management policies. Therefore, it is imperative that resource managers understand the factors influencing cattle distribution patterns. Biological mechanisms that influence distribution can be separated into two categories: abiotic, which pertains to the physical environment in which livestock graze (Coughenour 1991), and biotic, which encompass the characteristics of the grazing animal including social learning, spatial memory, and experience (Bailey et al. 1996).

Correspondence: Timothy DelCurto, Dept of Animal Sciences, Eastern Oregon Agriculture Research Center, Oregon State University, Union, OR 97883, USA. Email: tim.delcurto@oregonstate. edu

Manuscript received 16 July 2008; manuscript accepted 25 January 2009
The influence of environmental factors such as slope, aspect, forage production, and distance to water have been well documented in previous research (Mueggler 1965; Cook 1966; Roath and Krueger 1982; Ganskopp and Vavra 1987; Senft et al. 1987; Owens et al. 1991; Bailey et al. 1996; Walburger et al. 2000; Porath et al. 2002; DelCurto et al. 2005). However, interactions of these environmental factors with animal attributes are less understood.

Management options such as fencing, off-stream water, strategic placement of mineral blocks, improvement of trails, season of use, and herding have been shown as effective ways to alter distribution in order to promote sustainability (Skovlin 1965; Cook 1966; Bryant 1982; Roath and Krueger 1982; Porath et al. 2002; Parsons et al. 2003; DelCurto et al. 2005). It is often recommended that a combination of management options be used to meet goals for individual grazing situations (Bailey 2004). 
Table 1. Habitat variables used in logistic regression to estimate resource selection for various age classes of cattle in Bear Pasture, Starkey Experimental Forest and Range, northeastern Oregon (1991-2001).

\begin{tabular}{|c|c|c|c|c|}
\hline Habitat variable & Mean & SD & Minimum & Maximum \\
\hline Slope (\%) & 17 & 11 & 0 & 60 \\
\hline Sine aspect (negative no. $=$ west, positive no. $=$ east) & 0.07 & 0.8 & -1 & 1 \\
\hline Cosine aspect (negative no. $=$ south, positive no. $=$ north) & 0.15 & 0.6 & -1 & 1 \\
\hline Elevation $(\mathrm{m})$ & 1395 & 71 & 1170 & 1500 \\
\hline Convexity (negative no. $=$ concave, positive no. $=$ convex) & 500 & 4.8 & 473 & 518 \\
\hline Forage production $\left(\mathrm{kg} \cdot \mathrm{ha}^{-1}\right)$ & 324 & 99 & 0 & 1400 \\
\hline Soil depth $(\mathrm{cm})$ & 27 & 12 & 9 & 55 \\
\hline Distance to cover (m) & 103 & 124 & 0 & 806 \\
\hline Distance to water $(\mathrm{m})$ & 268 & 206 & 0 & 1188 \\
\hline Distance to cattle fence $(\mathrm{m})$ & 977 & 712 & 0 & 3224 \\
\hline Canopy (\%) & 28 & 20 & 0 & 85 \\
\hline
\end{tabular}

The direct influence of cattle age on grazing distribution has been previously studied (Neville 1971; Bryant 1982; Ralphs and Cheney 1993; Cazcarra and Petit 1995; Beaver and Olson 1997; Morrison 2002). However, the majority of the studies involving cow age as a direct factor influencing grazing behavior and distribution examined the effects of classes of livestock, i.e., yearlings vs. mature cow-calf pairs, or young cows vs. mature cows. The objective of this study was to assess the influence of age and experience by analyzing grazing behavior and distribution patterns of age classes of cattle within a large allotment pasture.

\section{MATERIALS AND METHODS}

\section{Study Area}

This study was conducted at the Starkey Experimental Forest and Range (Starkey) in the Wallowa-Whitman National Forest approximately $35 \mathrm{~km}$ southwest of La Grande, Oregon (lat $45^{\circ} 15^{\prime} \mathrm{N}$, long $\left.118^{\circ} 25^{\prime} \mathrm{W}\right)$. The $101-\mathrm{km}^{2}$ area is enclosed by a 2.3-m New Zealand game-proof fence (Skovlin 1991; Rowland et al. 1997). Starkey is typical spring, summer, and fall range for elk (Cervus elaphus) and mule deer (Odocoileus hemionus) in the Blue Mountains, with broad rolling uplands separated by moderately deep canyon drainages. Vegetation varies among coniferous forest, shrublands, and grasslands. A detailed description of the area can be found in Skovlin (1991) and Rowland et al. (1997).

Within the perimeter of the game fence, cattle fences divide the main allotment into four pastures (Smith-Balley, Halfmoon, Bear, and Cambell). Pastures are grazed using a deferred rotation grazing system. On even-numbered years, grazing is initiated in Cambell pasture and rotated through the system, ending in Smith-Bally pasture. The reverse is conducted on odd-numbered years, with grazing starting in Smith-Bally and concluding in Cambell pasture (Rowland et al. 1997).

We restricted our analysis to Bear Pasture because of its placement in the rotation and pasture size. Cattle graze Bear Pasture within approximately $2 \mathrm{wk}$ to $3 \mathrm{wk}$ at the same time each year for approximately $6 \mathrm{wk}$ each grazing season before being rotated to another pasture. Typical dates for grazing Bear Pasture are mid-July to end of August for even years and beginning of August to mid-September for odd years. Bear
Pasture is approximately 3300 ha and ranges in elevation from $1170 \mathrm{~m}$ to $1500 \mathrm{~m}$ with a mean elevation of $1395 \mathrm{~m}$ (Table 1). Riparian areas dominate lower elevations with wide expanses of rocky land with little or no soil cover in the upland areas. In addition, large areas of forested rangeland are interspersed throughout the pasture.

\section{Terrain and Habitat Variables}

Terrain and habitat characteristics of Starkey have been determined through an extensive process of aerial photo interpretation, satellite imagery, and intensive field data collection (Rowland et al. 1998; Johnson et al. 2000). Several variables were selected to represent each $30 \times 30 \mathrm{~m}$ pixel of Starkey in a geographic information database (GIS). These variables were developed using available literature examining elk, deer, and cattle distribution. Recorded features used in this study (Table 1) include percentage of slope (slope), sine of aspect (sine aspect), cosine of aspect (cosine aspect), convexity of landscape (convexity; Johnson et al. 2000), distance to perennial streams and developed water sources (distance to water), forage production long-term mean (Johnson et al. 2000 ), distance to nearest pixel with $>40 \%$ tree canopy cover (distance to cover), elevation, distance to cattle fence, canopy cover of trees $>12 \mathrm{~cm}$ diameter at breast height (canopy), and combined soil depths of the A and B horizons (soil depth).

\section{Monitoring Cattle Locations}

In this study, we used a LORAN-C automated telemetry system from 1991 to 2001. The automated telemetry system attempts to query a collar every $20 \mathrm{~s}$ and is operational $24 \mathrm{~h} \cdot \mathrm{d}^{-1}$ except during periods of equipment testing, maintenance, or repair. This schedule is equivalent to the same collar being queried approximately once every hour. In this analysis, we used 43039 cattle locations obtained between $1 \mathrm{~h}$ prior to sunrise until $4 \mathrm{~h}$ after sunrise and $4 \mathrm{~h}$ prior to sundown until $1 \mathrm{~h}$ after sundown from 269 animals. Individual animal was the experimental unit and an animal was removed from analysis if it had less than 50 locations in Bear Pasture for any given year (Johnson et al. 2000) during the grazing period. Each animal location was then assigned to a $30 \times 30 \mathrm{~m}$ pixel within the GIS. Mean positional error of the automated telemetry system was $\pm 53 \mathrm{~m}(\mathrm{SE}=5.9$; Findholt et al. 1996). Each location was 
Table 2. Number of cattle and observation totals used to determine resource selection functions, by age class, over a 10-yr period (19912001) in Bear Pasture, Starkey Experimental Forest and Range, northeastern Oregon.

\begin{tabular}{lccc}
\hline Age of cattle & $\begin{array}{c}\text { Total number } \\
\text { of cattle }\end{array}$ & $\begin{array}{c}\text { Total } \\
\text { observations }\end{array}$ & $\begin{array}{c}\text { Peak grazing } \\
\text { observations }^{1}\end{array}$ \\
\hline $2-3$ yr old & 72 & 17409 & 7762 \\
$4-5$ yr old & 92 & 33247 & 14871 \\
$6-7$ yr old & 57 & 21545 & 9759 \\
$\geq 8$ yr old & 48 & 23956 & 10647 \\
\hline
\end{tabular}

${ }^{1}$ Observations taken between $1 \mathrm{~h}$ before until $4 \mathrm{~h}$ after sunrise and $4 \mathrm{~h}$ before until $1 \mathrm{~h}$ after sunset.

weighted by the inverse of the observation rate for each pixel to correct for spatial bias (Johnson et al. 1998).

\section{Study Design}

All cattle used in this study grazed forested rangelands during the summer period ( 15 June to 15 October) every year and, as a result, were familiar with the habitat types and topography represented in Bear Pasture. For the purpose of this study, age is synonymous with experience grazing forested range types. Thirty to sixty cows $(496 \pm 60 \mathrm{~kg}$ initial body weight) from Eastern Oregon Agricultural Research Center herd were fitted with telemetry collars each year. The same cow was retained as a sampling unit as long as she remained reproductively successful. These cattle grazed in common with cattle from other ranchers (other permittees) for a total of 500 head in the pasture (stocking rate $4.4 \mathrm{ha} \cdot \mathrm{AUM}^{-1}$ [animal unit month]). Collared cattle were sorted into age classes in order to accurately analyze differences in distribution habits. Age classes were used because not all ages of cattle were represented in all years. Four age classes were established and cattle were assigned accordingly (Table 2). All collared cows were lactating and nursed their calves throughout the grazing period. Locations recorded from $1 \mathrm{~h}$ prior to sunrise until $4 \mathrm{~h}$ after sunrise and $4 \mathrm{~h}$ prior to sundown until $1 \mathrm{~h}$ after sundown were used in this study to reflect the peak grazing hours (Porath et al. 2002; Morrison 2002; Parsons et al. 2003). Analysis was limited to peak grazing times to determine habitat selection of foraging sites rather than general pasture occupancy.

\section{Statistical Analysis}

Resource selection functions (RSF) were calculated for each age class of cattle and for all cattle to identify the probability of the location of animals on a landscape (Johnson 1980; Boyce et al. 2002). RSFs are a form of habitat suitability index but with statistical rigor (Boyce et al. 2002). Logistic regression (PROC GENMOD; SAS Institute Inc., Cary, NC) was used in a stepwise backwards approach to identify variables in the RSF for each age class of cattle. The variance from PROC GENMOD was underestimated, because it was based on the number of locations for each animal. As a result, a jackknife procedure (Efron 1982; Johnson et al. 2000; Coe et al. 2001) was used to test the significance of the coefficients of the RSF. Within the jackknife procedure, a different animal is sequentially dropped from the analysis during each iteration, and the analysis is rerun to reduce the potential problem of autocor- relation among animal locations. The resulting coefficients were accumulated and the variance of each variable was analyzed for significance $(P<0.05)$ with Wald $\chi^{2}$ tests.

Starting with 11 habitat variables, we removed the one or two variables with the greatest $P$ value from the model after each iteration. This process was repeated until all remaining variables were significant $(P<0.05)$. The RSF probability for each of the 38213 pixels present in Bear Pasture was then calculated as $\mathrm{RSF}=\exp \left(\beta_{0}+\beta_{1} \mathrm{x}_{1}+\beta_{2} \mathrm{x}_{2} \ldots+\beta_{\mathrm{n}} \mathrm{x}_{\mathrm{n}}\right)$ using the nonstandardized coefficients of the significant variables (Johnson et al. 2000; Coe et al. 2001).

RSFs were estimated for each age class of cattle and final significant coefficients were standardized to facilitate comparisons between age classes. In addition, to evaluate if differing age classes were selecting resources similarly, we incorporated each age class RSF score as a variable in the logistic regression for all age classes as outlined in Johnson et al. (2000).

A repeated model using the MIXED procedures in SAS (SAS Institute Inc.) was used to determine the effects of the significant RSF habitat variables on the distribution patterns for the different age classes of cattle. Individual animal within year was the experimental unit, with the experiment being repeated across years. As well, individual animal and animal within year were added as random variables into the model. Compound symmetry was used as the covariance structure because it provided the best goodness of fit based on the Akaike's information criterion (Littell et al. 2006). Age class means for the habitat variables were separated using leastsquares means procedures of SAS (SAS Institute Inc.) and age class comparisons were considered significant at $P<0.05$.

\section{RESULTS}

\section{RSF}

Initial analysis indicated that year was not a significant factor influencing distribution; therefore, results are compiled from all years (1991-2001). Comparison of RSFs for each age class of animals revealed commonalities, as well as distinct differences in the variables that were significant determinants in resource selection (Table 3). Three of the 11 variables evaluated, sine of aspect, forage production, and distance to water, occurred in RSFs from all age classes. The magnitude of the standardized coefficient for distance to water was considerably greater than either sine of aspect or forage production, indicating that distance to water was driving resource selection to a greater extent than any other single habitat variable. All ages of animals selected west slopes, foraging locations with greater forage production, and sites farther from water than pasture averages. According to the RSFs, the majority of cattle were also selecting for gentler slopes and areas with less canopy coverage.

Elevation contributed to the RSF $(P<0.05)$ for cattle $\leq 3 \mathrm{yr}$ of age and $\geq 8 \mathrm{yr}$ of age, but it was not significant $(P>0.05)$ for cattle 4-7 yr of age. However, 2-3-yr-olds had a coefficient of -0.28 and cattle $\geq 8 \mathrm{yr}$ of age had a coefficient of 0.20 , indicating that younger cattle selected lower elevation sites whereas older cattle selected higher elevation sites.

When we incorporated each age class RSF score as a variable in the logistic regression for all age classes, all were positive and 
Table 3. Variables in models of resource selection function of age classes of cattle from 1991 to 2001 using locations obtained with a LORAN-C automated telemetry system in Bear Pasture, Starkey Experimental Forest and Range, northeastern Oregon.

\begin{tabular}{|c|c|c|c|c|c|c|c|c|c|}
\hline & Intercept & Slope & Sine aspect & Elevation & Convexity & $\begin{array}{c}\text { Forage } \\
\text { production }\end{array}$ & $\begin{array}{l}\text { Soil } \\
\text { depth }\end{array}$ & $\begin{array}{l}\text { Distance } \\
\text { to water }\end{array}$ & Canopy \\
\hline \multicolumn{10}{|l|}{ All cattle } \\
\hline$\beta$ & 2.71 & -0.009 & -0.15 & & -0.01 & 0.001 & & 0.002 & -0.003 \\
\hline Stand. $\beta^{1}$ & -1.92 & -0.10 & -0.12 & & -0.05 & 0.14 & & 0.34 & -0.06 \\
\hline $\mathrm{SE}^{2}$ & 0.07 & 0.02 & 0.01 & & 0.01 & 0.01 & & 0.02 & 0.01 \\
\hline$P$ value & $<0.001$ & $<0.001$ & $<0.001$ & $\mathrm{~ns}^{3}$ & $<0.001$ & $<0.001$ & ns & $<0.001$ & $<0.001$ \\
\hline \multicolumn{10}{|c|}{ 2-3-yr-old cattle } \\
\hline$\beta$ & 1.17 & -0.01 & -0.13 & -0.004 & & 0.002 & -0.004 & 0.002 & \\
\hline Stand. $\beta$ & -3.63 & -0.12 & -0.10 & -0.28 & & 0.15 & -0.05 & 0.31 & \\
\hline SE & 0.07 & 0.04 & 0.02 & 0.07 & & 0.01 & 0.02 & 0.03 & \\
\hline$P$ value & $<0.001$ & 0.01 & $<0.001$ & $<0.001$ & ns & $<0.001$ & 0.05 & $<0.001$ & ns \\
\hline \multicolumn{10}{|c|}{ 4-5-yr-old cattle } \\
\hline$\beta$ & -3.83 & & -0.16 & & & 0.001 & & 0.002 & -0.003 \\
\hline Stand. $\beta$ & -2.98 & & -0.12 & & & 0.14 & & 0.37 & -0.06 \\
\hline SE & 0.05 & & 0.02 & & & 0.01 & & 0.02 & 0.01 \\
\hline$P$ value & $<0.001$ & ns & $<0.001$ & ns & ns & $<0.001$ & ns & $<0.001$ & $<0.001$ \\
\hline \multicolumn{10}{|c|}{ 6-7-yr-old cattle } \\
\hline$\beta$ & 3.17 & -0.02 & -0.14 & & -0.01 & 0.001 & & 0.001 & -0.003 \\
\hline Stand. $\beta$ & -3.43 & -0.19 & -0.11 & & -0.07 & 0.11 & & 0.30 & -0.05 \\
\hline SE & 0.06 & 0.06 & 0.02 & & 0.02 & 0.01 & & 0.03 & 0.02 \\
\hline$P$ value & $<0.001$ & 0.003 & $<0.001$ & ns & 0.002 & $<0.001$ & ns & $<0.001$ & 0.009 \\
\hline \multicolumn{10}{|c|}{$\geq 8$-yr-old cattle } \\
\hline$\beta$ & 3.13 & -0.004 & -0.15 & 0.003 & -0.02 & 0.001 & & 0.002 & -0.003 \\
\hline Stand. $\beta$ & -3.41 & -0.10 & -0.12 & 0.20 & -0.11 & 0.12 & & 0.34 & -0.06 \\
\hline SE & 0.11 & 0.04 & 0.02 & 0.09 & 0.03 & 0.01 & & 0.04 & 0.02 \\
\hline$P$ value & $<0.001$ & 0.03 & $<0.001$ & 0.03 & 0.006 & $<0.001$ & ns & $<0.001$ & 0.004 \\
\hline
\end{tabular}

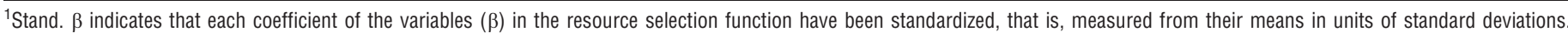
${ }^{2} \mathrm{SE}$ is of standardized coefficients $(\beta)$.

${ }^{3}$ ns indicates not significant $(P>0.05)$.

of similar magnitude. The lowest coefficient values were between $2-3$-yr-old cattle and cattle $\geq 8$ yr of age (standardized $\beta=0.21$ ), whereas the greatest similarities occurred between $6-7$-yr-old cattle and cattle $\geq 8$ yr of age (standardized $\beta=0.32$ ).

\section{Terrain and Habitat Use by Age Class}

Because year was not a significant factor in RSFs, means for habitat variables for each age class are compiled for all years (1991-2001) to aid in comparisons with RSFs. Age classes differed for 8 of the 11 habitat variables analyzed, percentage of slope, cosine of aspect, elevation, distance to cover, distance to water, convexity, forage production, and percentage of canopy cover (Table 3; Fig. 1).

Younger cattle, 2-3 yr of age, selected sites on steeper slopes $(P<0.05)$ and at lower elevations $(P<0.05)$ than cattle $\geq 8$ yr of age. Cattle $\geq 8 \mathrm{yr}$ of age also selected foraging locations approximately $20 \mathrm{~m}$ farther from $>40 \%$ canopy cover $(P<0.05)$ than $2-3$-yr-olds. All cattle selected feeding locations in more open canopies (Fig. 1), but 2-3-yr-olds foraged in sites with greater canopy cover $(P<0.05)$ than other age classes. Cattle in all age classes selected foraging sites with greater forage production and farther from water, whether developed water or perennial streams, than the average for Bear Pasture (Fig. 1).

\section{DISCUSSION}

We were able to quantify the influence of age of cattle on differences in habitat use and distribution for cattle grazing Starkey Experimental Forest and Range during late July through mid-September. Two distinct habitat variables, forage production and distance to water (Table 3), were significant in RSFs calculated from all age classes and all ages of cattle selected sites that had greater forage production and were farther from water than the average of the study pasture. These results are congruent to those found by previous studies (Mueggler 1965; Cook 1966; Roath and Krueger 1982; Senft et al. 1987; Owens et al. 1991; Bailey et al. 1996; Kie and Boroski 1996; Parsons et al. 2003; Walburger et al. 2000; Coe et al. 2001; Porath et al. 2002), that distance to water and available forage are key determinants in distribution.

Porath et al. (2002), Parsons et al. (2003), and Morrison (2002) have reported a diurnal pattern of grazing, with the 

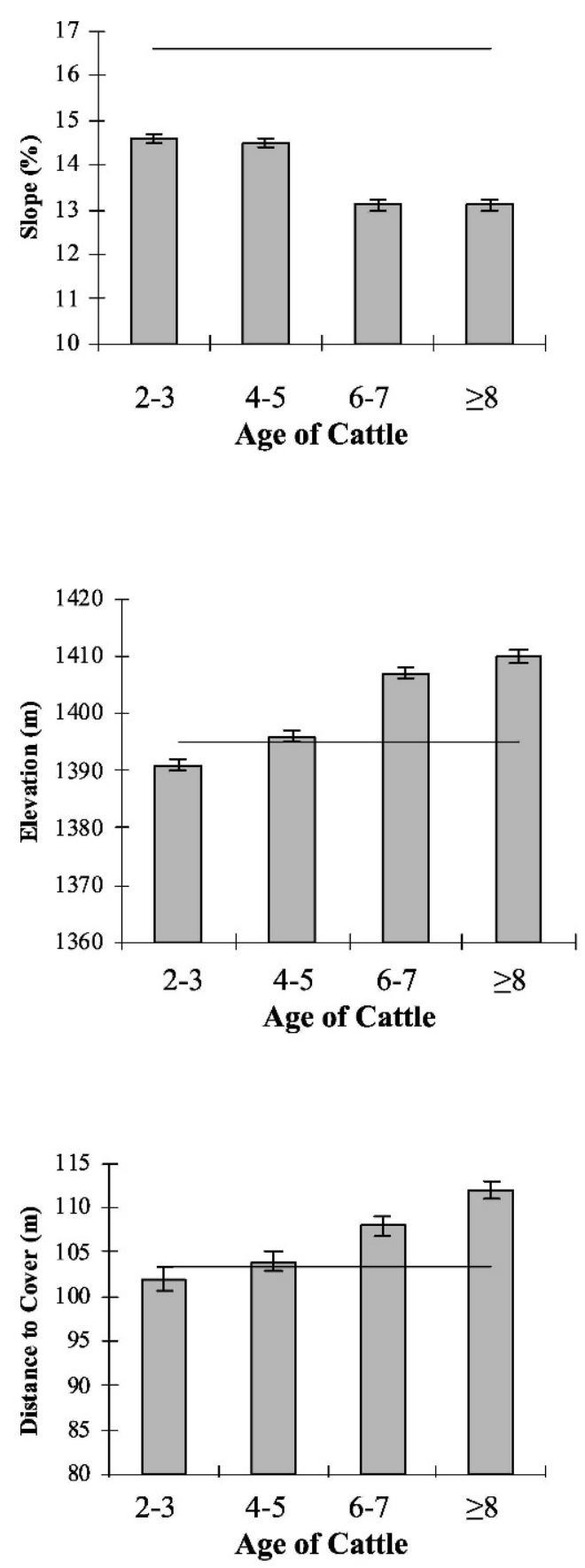
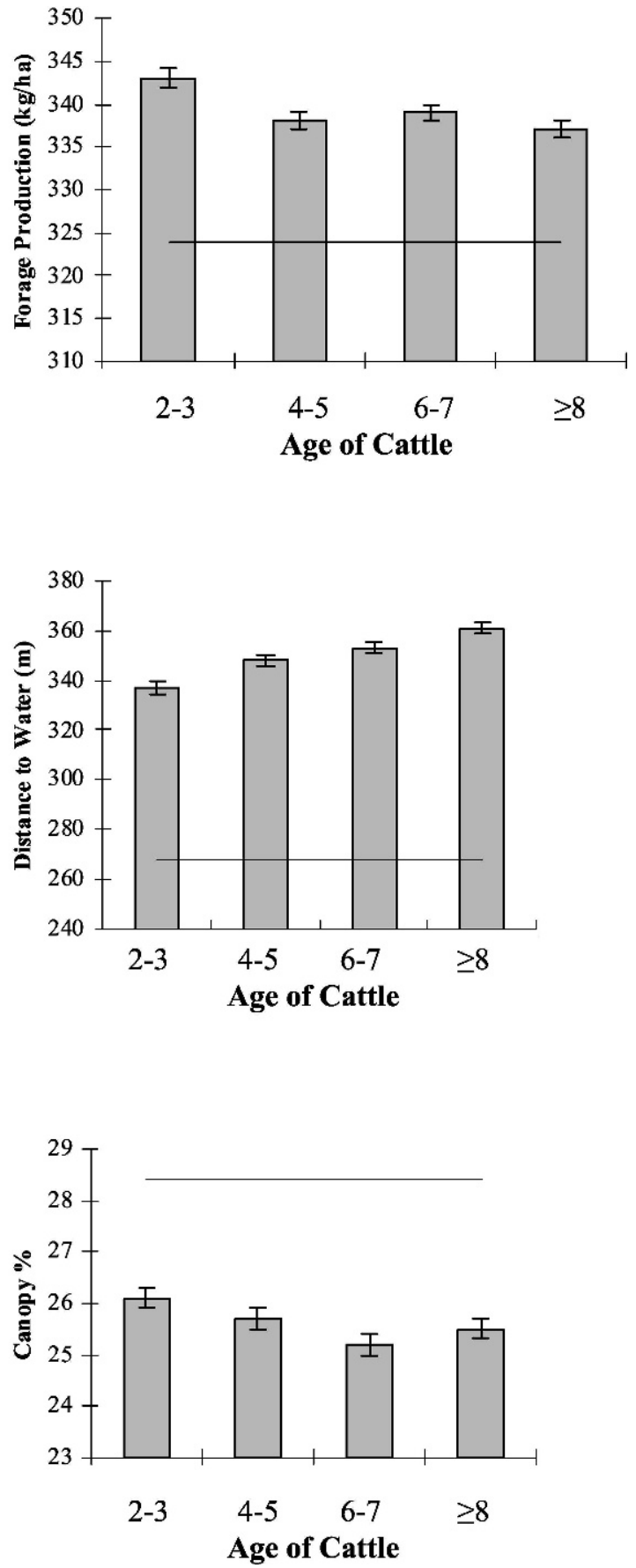

Figure 1. Mean use by various ages of cattle for alternative measures of terrain and habitat during peak grazing hours (1 $\mathrm{h}$ before and $4 \mathrm{~h}$ after sunrise and $4 \mathrm{~h}$ before and $1 \mathrm{~h}$ after sunset), in Bear Pasture, Starkey Experimental Forest and Range, northeastern Oregon. The mean for Bear Pasture for each terrain or habitat variable is represented by the solid horizontal line. Error bars represent standard error of the means.

majority of grazing occurring $1 \mathrm{~h}$ prior to sunrise until $4 \mathrm{~h}$ after sunrise and $4 \mathrm{~h}$ prior to sundown until $1 \mathrm{~h}$ after sundown. By limiting observations to these peak grazing times we were able to determine important foraging areas rather than general pasture occupancy. Roath and Krueger (1982), Parsons et al. (2003), and Coe et al. (2001) reported that cattle were selecting areas closer to water later in the grazing season, whereas Howery et al. $(1996,1998)$ and this study concluded that cattle were selecting foraging areas farther from water during midsummer (mid-July to the end of August). Two factors may explain why cattle in our study were observed relatively far from water. First, cattle observations within our study were taken during the peak grazing times rather than throughout the entire day, thereby eliminating observations taken during periods of rest, environmental stress (midday heat), and movement to water. Second, upland vegetation was not as senescent as vegetation is in late-summer studies of Roath and Krueger (1982), Parsons et al. (2003), and Coe et al. (2001).

In our analysis, we found age of cattle influenced distribution patterns with respect to water; younger cattle averaged $24 \mathrm{~m}$ 
closer to water than older cattle. Morrison (2002) noted similar patterns of distribution between first-calf heifers and mature cow-calf pairs in a mixed-conifer forest in northeastern Oregon. Bailey et al. (2006) found that older cows ( $>4 \mathrm{yr}$ of age) used steeper slopes and areas farther from water than younger cows (3-4 yr of age) in a Montana study using global positioning system tracking collars. However, in an earlier study, Bailey et al. (2001) reported that younger cattle traveled farther, both vertically and horizontally, than older cattle in one of the $2 \mathrm{yr}$ of visual observations recorded during the early morning, but in the second year, there were no differences in age classes. Bryant (1982) also documented that from mid-July to mid-August yearlings distributed farther from water than cow-calf pairs, but at later dates, there were no differences between yearlings and cow-calf pairs.

Forage production affected grazing distribution of all age classes of cattle (Table 3). Cattle in all age classes occupied areas with higher forage production than the mean value of the pasture (Fig. 1). Other researchers (Harris 1954; Roath and Krueger 1982; Gillen et al. 1984) reported that cattle disproportionately utilized areas of greater production.

Cattle preferred open areas with less canopy cover (Fig. 1), which is consistent with findings by Young et al. (1967), who noted lower use levels in areas under dense canopies. Miller and Krueger (1976) reported that canopy cover (\%) in conjunction with distance to water and soil depth, was negatively correlated with utilization. Areas of lower canopy cover generally produce greater levels of understory production (Young et al. 1967). Therefore, the relationship between cattle location and canopy cover and forage production noted in this study was not unexpected.

All age classes of cattle were attracted to west-facing slopes (Table 3). Sheehy and Vavra (1996) concluded that cattle utilized areas encompassing all aspects, suggesting that available forage found on varying aspects was the primary factor influencing distribution. As previously stated, cattle were choosing areas of higher forage production: in the case of this pasture, west-facing slopes.

Mueggler (1965), Bryant (1982), and Gillen et al. (1984) determined that cattle utilized areas with gentler slopes to a greater extent than steeper slopes. Ganskopp and Vavra (1987) also demonstrated the preference of cattle for slopes of $0 \%$ to $9 \%$, and an aversion to slopes greater than $20 \%$. All age classes of cattle in this study occupied gentler slopes than pasture average, but cattle $<5 \mathrm{yr}$ of age used steeper slopes as compared to cattle $>5 \mathrm{yr}$ of age, indicating that younger cattle were using foraging sites closer to water. Bryant (1982) also concluded that older cattle used a wider variety of slope classes than yearlings.

Beaver and Olson (1997) concluded that 3-yr-old cattle were less efficient at using a pasture's forage than 7- and 8-yr-old cattle. Cattle $2-3$ yr of age tended $(P=0.10)$ to remain closer to cattle fences, implying that younger cattle have less experience within the pasture compared to older cattle. Older cattle traveled to higher elevations for foraging locations, which may be the result of older cattle learning to use trails and roads to more efficiently gain access to these areas. Roath and Krueger (1984) commented that roads play a key role in cattle movements across steep and broken terrain.
Sheehy and Vavra (1996) indicated that elevation influenced cattle selection due to changes in plant community structure at differing elevations. Changes in canopy cover influence plant community structure and forage production. Differences in vegetation due to elevational gradients and canopy cover are present on our study site as well. In our study, significant habitat variables were similar across age classes. However, differences in magnitude of response to habitat variables among age classes occurred. Cattle 2-3 yr of age utilized areas lower in elevation and closer to cover and water, whereas cattle $\geq 8 \mathrm{yr}$ of age used areas of higher elevation farther from cattle fences, cover, and water.

This study was not designed to differentiate between age and experience, because once a cow received a telemetry collar the same cow was continually used until she was culled from the herd. Bailey (2005) suggested that more experienced animals may be more willing to use areas farther from water, to climb higher, or to graze steeper slopes. However, the cattle used in this study were not naive to the plant communities or the types of terrain found in Bear Pasture because they either grazed forested rangelands that were similar to Starkey or they actually grazed Bear Pasture when they were calves.

\section{IMPLICATIONS}

Cattle distribution patterns on western rangelands are characterized by interactions among diverse landscape features. Our results indicate habitat characteristics and age of cattle influence subsequent distribution patterns of cattle upon the landscape. Successful development of an understanding of sitespecific interactions between landscape characteristics, i.e., slope, elevation, distance to water, available forage, and the class of cattle present on the landscape affords managers an additional tool in resource utilization management. Older cattle with greater experience on forested rangelands may be better suited for use in pastures where riparian area stubble height is a trigger for pasture movement due to their tendencies to graze areas of higher elevation farther from water with lower levels of forage production. Younger cattle may graze critical pastures during cooler times of the year or in separate pastures. Herding or other management strategies can be used with younger cows to ensure riparian standards are met and to help them learn to move away from water. Our data may also be used by managers developing initial stocking rates for similar ranges. Understanding how age can affect how cows use various habitats allows managers to better classify forage as available or unavailable for cattle grazing and develop more accurate stocking rates. However, with all sampling confined to a single pasture, application of these findings to different environments should be made with some reservations.

\section{LITERATURE CITED}

Balley, D. W. 2004. Management strategies for optimal grazing distribution and use of arid rangelands. Journal of Animal Science 82(Electronic suppl.):E147-E153. Available at: http://jas.fass.org/cgi/reprint/82/13_suppl/E147. Accessed 15 April 2009.

Balley, D. W. 2005. Identification and creation of optimal habitat conditions for livestock. Rangeland Ecology and Management 58:109-118. 
Bailey, D. W., J. E. Gross, E. A. Laca, R. L. Rittenhouse, D. M. Coughenour, D. M. Swift, And P. L. Sims. 1996. Mechanisms that result in large herbivore grazing distribution patterns. Journal of Range Management 49:386-400.

Balley, D. W., D. D. Kress, D. C. Anderson, D. L. Boss, and E. T. Miller. 2001. Relationship between terrain use and performance of beef cows grazing foothill rangeland. Journal of Animal Science 79:1883-1891.

Bailey, D. W., H. C. Vanwagoner, and R. Weinmeister. 2006. Individual selection has the potential to improve uniformity of grazing on foothill rangeland. Rangeland Ecology and Management 59:351-358.

Beaver, J. M., And B. E. OLson. 1997. Winter range use by cattle of different ages in southwestern Montana. Applied Animal Behaviour Science 51:1-13.

Boyce, M. S., P. R. Vernier, S. E. Nielsen, and F. K. A. Schmiegelow. 2002. Evaluating resource selection functions. Ecological Modelling 157:281-300.

Bryant, L. D. 1982. Response of livestock to riparian zone exclusion. Journal of Range Management 35:780-785.

Cazcarra, R. F., and M. Petit. 1995. The influence of animal age and sward height on the herbage intake and grazing behaviour of Charolais cattle. Animal Science 61:497-506.

Coe, P., B. K. Johnson, J. W. Kern, S. L. Findholt, J. G. Kie, and M. J. Wisdom. 2001. Responses of elk and mule deer to cattle in summer. Journal of Range Management 54:A51-A76.

Cook, C. W. 1966. Factors affecting utilization of mountain slopes by cattle. Journal of Range Management 19:200-204.

Coughenour, M. B. 1991. Spatial components of plant-herbivore interactions in pastoral, ranching, and native ungulate ecosystems. Journal of Range Management 44:530-542.

Delcurto, T., M. Porath, C. T. Parsons, and J. A. Morrison. 2005. Management strategies for sustainable beef cattle grazing on forested rangelands in the Pacific Northwest. Rangeland Ecology and Management 58:119-127.

Efron, B. 1982. The jackknife, the bootstrap, and other resampling plans. In: CBMS-NSF Monograph 38. Society for Industrial and Applied Mathematics. Montpellier, VT, USA: Capital City Press. 92 p.

Findholt, S. L., B. K. Johnson, L. D. Bryant, and J. W. Thomas. 1996. Corrections for positional bias of a Loran-C radio telemetry system using DGPS. Northwest Science 70:273-280.

Ganskopp, D., AND M. VavRa. 1987. Slope use by cattle, feral horses, deer, and bighorn sheep. Northwest Science 61:74-81.

Gillen, R. L., W. C. Krueger, and R. F. Miller. 1984. Cattle distribution on mountain rangeland in northeastern Oregon. Journal of Range Management 37:549-553.

HarRIS, R. W. 1954. Fluctuations in forage utilization on Ponderosa pine ranges in eastern Oregon. Journal of Range Management 7:250-255.

Howery, L. D., F. D. Provenza, R. E. Banner, and C. B. Scott. 1996. Differences in home range and habitat use among individuals in a cattle herd. Applied Animal Behaviour Science 49:305-320.

Howery, L. D., F. D. Provenza, R. E. Banner, and C. B. Scott. 1998. Social and environmental factors influence cattle distribution on rangeland. Applied Animal Behaviour Science 55:231-244.

Johnson, B. K., A. A. Agar, S. L. Findholt, M. J. Wisdom, D. B. MarX, J. W. Kern, and L. D. Bryant. 1998. Mitigating spatial differences in observation rate of automated telemetry systems. Journal of Wildlife Management 62:958-967.

Johnson, B. K., J. W. Kern, M. J. Wisdom, S. L. Findholt, and J. G. Kie. 2000 Resource selection and spatial separation of mule deer and elk during spring. Journal of Wildlife Management 64:685-697.

Johnson, D. H. 1980. The comparison of usage and availability measurements for evaluating resource preference. Ecology 61:65-71.
KIE, J. G., AND B. B. Boroski. 1996. Cattle distribution, habits, and diets in the Sierra Nevada of California. Journal of Range Management 49:482-488.

Littell, R. C., G. A. Milliken, W. W. Stroup, R. D. Wolfinger, and O. Schabenberger. 2006. SAS for mixed models. 2nd ed. Cary, NC, USA: SAS Institute Inc. 813 p.

Miller, R. F., And W. C. Krueger. 1976. Cattle use on summer foothill rangelands in northeastern Oregon. Journal of Range Management 29:367-371.

Morrison, J. A. 2002. The influence of cow age on grazing distribution and utilization of mountain riparian areas and adjacent uplands [thesis]. Corvallis, OR, USA: Oregon State University. $101 \mathrm{p}$

Mueggler, W. F. 1965. Cattle distribution on steep slopes. Journal of Range Management 18:255-257.

NeviLLE, W. E. 1971. Effect of age on the energy requirements of lactating Hereford cows. Journal of Animal Science 33:855-860.

Owens, M., K. L. Launchbaugh, and J. W. Holloway. 1991. Pasture characteristics affecting spatial distribution of utilization by cattle in mixed brush communities. Journal of Range Management 44:118-123.

Parsons, C. T., P. A. Momont, T. Delcurto, M. Mclnnis, and M. L. Porath. 2003. Cattle distribution patterns and vegetation use in mountain riparian areas. Journal of Range Management 56:334-341.

Porath, M. L., P. A. Momont, T. Delcurto, N. R. Rimbey, J. A. Tanaka, and M. Mclnnis. 2002. Offstream water and trace mineral salt as management strategies for improved cattle distribution. Journal of Animal Science 80:346-356.

Ralphs, M. H., and C. D. Cheney. 1993. Influence of cattle age, lithium chloride, dose level, and food type in the retention of food aversions. Journal of Animal Science 71:373-379.

Roath, L. R., and W. C. Krueger. 1982. Cattle grazing and behavior on a forested range. Journal of Range Management 35:332-338.

Rowland, M. M., L. D. Bryant, B. K. Johnson, J. H. Noyes, M. J. Wisdom, and J. W. Thomas. 1997. The Starkey project: history, facilities, and data collection methods for ungulate research. Portland, OR, USA: USDA USFS Technical Report PNW-GTR-396. 62 p.

Rowland, M. M., P. K. Coe, R. J. Stussy, A. A. Ager, N. J. Cimon, B. K. Johnson, and M. J. WISDOM. 1998. The Starkey habitat database for ungulate research: construction, documentation and use. Portland, OR, USA: USDA USFS Technical Report PNW-GTR-430. $48 \mathrm{p}$.

Senft, R. L., M. B. Coughenour, D. W. Balley, L. R. Rittenhouse, O. E. Sala, and D. M. Swift. 1987. Large herbivore foraging and ecological hierarchies. BioScience 37:789-799.

SheeHy, D. P., and M. Vavra. 1996. Ungulate foraging areas on seasonal rangeland in northeastern Oregon. Journal of Range Management 49:16-23.

SKovLIN, J. M. 1965. Improving cattle distribution on western mountain rangelands. Washington, DC, USA: US Department of Agriculture, Farmers' Bulletin No. 2212. p. 1-14.

SKovLIN, J. M. 1991. Fifty years of research progress: a historical document on the Starkey Experimental Forest and Range. Portland, OR, USA: USDA USFS Technical Report PNW-GTR-266. 58 p.

Walburger, K., T. Delcurto, M. Vavra, L. Bryant, and J. G. Kie. 2000. Influence of a grazing system and aspect, north vs. south, on the nutritional quality of forages, and performance and distribution of cattle grazing forested rangelands. In: Proceedings of the Western Section, American Society of Animal Science; 20-23 June 2000, Davis, CA, USA. Savoy, IL, USA: American Society of Animal Science. p. 181-184.

Young, J. A., A. B. McArthur, and D. W. Hedrick. 1967. Forage utilization in a mixed-conifer forest in northeastern Oregon. Journal of Forestry 65:391-393. 